\title{
Economic analysis of milk production in eastern region of India
}

\author{
Binita kumari, BS Chandel and Priyanka Lal
}

Received: 10 June 2020 / Accepted: 16 August 2020 / Published online: 27 October 2020

(C) Indian Dairy Association (India) 2020

\begin{abstract}
India maintains the top most position in milk production due to the continuous efforts of the dairy farmers of the nation who have been consistent in dairying sector despite all the vagaries. Profitability in dairy farming is important to keep the farmer into the business. Keeping this in mind the present study was taken in eastern region of India with an aim to find out the cost and return per litre of milk. The study concluded that about fifty per cent of total feed and fodder cost was incurred on concentrate and the cost incurred on feeding buffaloes was maximum followed by crossbred and local cows. About ninety per cent of the labour cost was on own family labour. Return per litre from milk was highest for crossbred and the least for local cow and it varied positively with the herd size. It was also found that the income from sale of milk can be increased if expenditure on green fodder, dry fodder, concentrate and labour used are increased Also, the farmers in the study area are over using green fodder, optimally using dry fodder and under using concentrate and labour in milk production.
\end{abstract}

Keywords: Cost, Milk production, Marginal Value Productivity, Profit, Return

Department of Dairy Economics Statistics and Management, ICARNational Dairy Research Institute, Karnal-132 001, India

Binita Kumari ( $₫)$

Department of Dairy Economics Statistics and Management, ICAR-National Dairy Research Institute, Karnal-132 001, India Email: b.binitakumari@gmail.com

\section{Introduction}

Dairy farming is an important source of secondary income for over 70 million milk producers, signifying its role to alleviate rural income and employment. Every second household in rural India undertakes dairy farming either as a primary or secondary means of occupation. Its role in food and nutritional security can't be overlooked in a country having one third people below poverty line. Milk is an important food item in the consumption basket of every Indian. It's important not only from consumption point of view but also from production point of view. India ranks number one in world in milk production with a milk production of 176.3 milllion tonnes (NDDB, 2019). If the country is to meet the consumption demands of the nation as well as maintain the top position as milk producing nation, then dairy farming must be a profitable business. Profit depends both on cost and yield as profit can be increased either by lowering cost of production or by improving the productivity of the animals. We are well aware that law of diminishing returns operates in dairy farming too. Hence, there is a limit to which the yield can be improved. Therefore, more emphasis should be given to lowering of the cost of milk production. Also, special attention should be given towards proper disposal of milk by eliminating the middlemen in the marketing chain, thereby, providing remunerative prices to the farmers. The present study focuses on eastern parts of the country as the region has immense scope in dairy development as it harbours about 23 per cent of total cows and buffaloes in the country. Despite of the fact that the region has about one fourth of milch animals, it handles only about 12 per cent of the total milk produced in the country and the milk production is growing at a rate of 4 per cent.

Many studies have been carried out to find the cost and returns of milk production in specific states or districts (Chand et al. 2017; Keerthi and Paramsivam, 2019; Kumari et al. 2016; Kumawat et al. 2016; Patel and Ashwar, 2019; Singh et al. 2017; Tanwar et al. 2012). In this paper the economics of milk production has been worked out for whole of the eastern region. The paper also establishes the milk production function for the eastern region and also finds out the resource use efficiency of the various inputs. Similar study has been carried out by Bhagat et al. 2016; 
Kumari and Malhotra, 2018; Lalrinsangpuii and Malhotra, 2016; Mehra et al. 2018; Vishnoi et al. 2015 etc.

\section{Material and Methods}

The eastern region of India encompasses of the states of West Bengal, Odisha, Chhattisgarh, Bihar, Assam, Eastern Uttar Pradesh and Jharkhand. Based on the per capita availability of milk, (Bihar (195 gm/day), Jharkhand (146 gm/day), West Bengal (145 gm/day), Chhattisgarh (130 gm/day), Odisha (122 gm/day) and Assam (69 gm/day)), the states of Bihar, West Bengal and Jharkhand were selected. From each state, one district was selected on the basis of highest livestock population density. Hence, the districts of Madhepura (0.88), Deoghar (0.37) and Hooghly (0.49) were selected from the states of Bihar, Jharkhand and West Bengal, respectively (The values in parentheses being the livestock population density of the districts). From each district, one tehsil was selected randomly, from which two villages were randomly selected. 300 respondents were selected according to probability proportional allocation from these six villages. Complete enumeration of these villages was done and strata were formed using cumulative square root frequency method. Three herd size categories were formed namely, small (1-3 milch animals), medium (4 and 5 milch animals) and large ( $>5$ milch animals). Table 1 shows the sample distribution in the study area.

Every herd comprised animals of different age groups, types (crossbred, buffaloes, and local cows) and sex (male, female). Joint costs such as fixed costs and labour utilisation will be different across these categories of animals, hence apportionment of joint costs becomes necessary. For this purpose the different categories of animals were converted into homogenous animal units known as Standard Animal Units (SAUs). SAUs as suggested by Sirohi et al. 2015 (Table 2) were used for this purpose.

Total costs comprises of total variable cost and total fixed cost. Fixed cost: They do not vary with the level of output and remain unchanged over a short period of time. They included the cost of durable assets like farm inventory, cattle inventory, farm equipments etc. and were taken care of by charging depreciation on purchase cost. Depreciation was calculated using Capital Recovery Cost method. The CRC method is defined as the annual payment that will repay the cost of fixed input over the useful life of input and provide an economic rate of return on investment. The formula for estimation of CRC for farm inventory and equipments is as follows:

$$
R=Z\left\lfloor\frac{(1+r)^{n} r}{(1+r)^{n}-1}\right\rfloor
$$

Where: $\mathrm{R}=$ Capital recovery cost, $\mathrm{Z}=$ Initial value of the capital asset, $r=$ interest rate, $n=$ useful life of the assets

The total CRC was calculated using the above formulae and was later apportioned among individual animals using SAUs. Formula for CRC estimation for cattle is same as that of above but the value of ' $n$ ' has to be ascertained differently for each animal. Generally, the productive life of crossbred is taken as 8 years ( 5 calvings) and of local cow and buffalo as 10 years ( 6 calvings). But, these cannot be used as such because using the value of the animal at the time of birth won't be appropriate. The value of the animal varies with wet-dry status, pregnancy (pregnant or non-pregnant), order of lactation, stage of lactation, etc. Hence, the estimation of CRC

Table 1 Population of dairy households and their sample sizes in the study area

\begin{tabular}{|c|c|c|c|c|c|c|c|}
\hline State & District & Tehsil & Village & Small & Medium & Large & Total \\
\hline \multirow[t]{2}{*}{ Bihar } & Madhepura & Madhepura & Gamarhia & $34(46)$ & $23(31)$ & $6(7)$ & $63(84)$ \\
\hline & & & Bakhri & $29(39)$ & $14(19)$ & $6(8)$ & $49(66)$ \\
\hline \multirow[t]{2}{*}{ Jharkhand } & Deoghar & Sarath & Gajiadih & $27(36)$ & $14(18)$ & $7(9)$ & $48(63)$ \\
\hline & & & Gaura & $31(41)$ & $20(27)$ & $6(8)$ & $57(76)$ \\
\hline \multirow[t]{2}{*}{ West Bengal } & Hooghly & Khanakul & Nabasan & $27(35)$ & $11(14)$ & $3(4)$ & $41(53)$ \\
\hline & & & Dainan & $34(44)$ & $6(9)$ & $2(2)$ & $42(55)$ \\
\hline
\end{tabular}

Note: The figures in the parentheses indicate the total dairy households in the sample village

Table 2 Standard Animal Units for eastern region in India

\begin{tabular}{|c|c|c|c|c|c|c|c|c|}
\hline & & $\begin{array}{l}\text { Adult } \\
\text { male }\end{array}$ & $\begin{array}{l}\text { Adult } \\
\text { female }\end{array}$ & $\begin{array}{l}\text { Young stock } \\
M<1\end{array}$ & $\begin{array}{l}\text { Young stock } \\
M<1\end{array}$ & $\begin{array}{l}\text { Young stock } \\
M<1\end{array}$ & $\begin{array}{l}\text { Young stock } \\
M<1\end{array}$ & Heifer \\
\hline \multirow[t]{2}{*}{ East } & $\mathrm{CB}$ & 1.07 & 1.20 & 0.25 & 0.24 & 0.51 & 0.38 & 0.71 \\
\hline & $\mathrm{LC}$ & 0.92 & 1.00 & 0.27 & 0.24 & 0.41 & 0.37 & 0.64 \\
\hline
\end{tabular}

Note: CB: Crossbred, LC: Local Cow, BU: Buffalo 
based on the current value of milch animal is appropriate rather than considering their initial value. When current value is taken into account, ' $n$ ' has to be worked out as the length of remaining productive life.

$$
\begin{gathered}
n=[\text { maximum aling }-1) \times \text { inter cainug penod }]-[\text { (number of cahings doue } \\
-1) \times \text { ater cahng period }]+ \text { lactation length }
\end{gathered}
$$

If inter calving period and lactation length is in months then the formula needs to be divided by 12 for conversion into years. One more thing that has to be taken care of in case of animals is that $\mathrm{Z}$ in the formulae is net current value of the animal i.e., current value - salvage value as the salvage value in case of animals is quite high at the end of productive life.

Variable cost: These are those costs, which are incurred on the variable factors of production and can be altered in the short run. Variable cost includes four items i.e. feed and fodder cost, labour cost, veterinary cost and miscellaneous expenditure.

Feed and fodder cost included the cost incurred on feeding green fodder, dry fodder and concentrate to animals. If the concentrate was homemade then the weighted average of prices of all the ingredients was taken to ascertain the price of concentrate.

Labour was differentiated into hired labour and own labour. One man day was considered of 8 hours. For estimation of labour cost in case of women labourers, total time spent on different dairy activities was converted to man days by using conversion as:

$$
1 \text { day of women labour }=0.67 \text { man day }(3 \text { women }=2 \text { men })
$$

\section{Cost of grazing of animals was also included in labour cost}

The expenditure on breeding and health care of the animals was covered under the veterinary expense. It included, cost of artificial insemination (AI), natural service, vaccination, medicines, fee of veterinary doctor and other related expenses. The miscellaneous expenditure included expenses on repair of fixed assets, water and electricity charges, insurance premium and any other incidental charges. These being joint costs, apportionment of the same based on SAU were done.

Later gross cost was calculated as the sum of total fixed cost (CRC), feed and fodder cost, labour cost and miscellaneous cost. Subsequently, value of dung was deducted from gross cost to arrive at net cost. Further, gross returns, net returns and cost per litre of milk were calculated. Also, in order to find out the impact of expenditure on various variable inputs on income earned from selling of milk the expenditure incurred on green fodder, dry fodder, concentrate, labour and miscellaneous inputs per farm per day were regressed on income in a dairy household from selling of milk. Different functional forms were tried and log-log form was found to be best fit. Marginal value product of these inputs was found using the formula MVP $=b_{i} x \frac{T}{x}$ in case of log-log functional form.

\section{Results and Discussion}

In order to have a sustainable dairy farming business, the farmers must realise high milk yield. Milk yield from animals depends not only on breed and management practices but also, on feed and fodder provided to the animals. But farmers just can't go on feeding the animals with a hope to have a high milk yield. They have to keep in mind the cost incurred on feeding the animals. In the study area, animals were given green fodder in the form of chopped maize stalks and Diancha leaves. Dry fodder was given in the form of bhusa whereas concentrate was mostly homemade consisting of grains and food left over after human consumption. Table 3 shows the quantity of feed and fodder fed to each animal per day. Local cows are not given much feed and fodder as compared to crossbred cow and buffalo. Proper care of local cattle diet is not taken as their yield is low and because their yield is low they aren't fed properly. They are given mostly the maintenance ration. Thus a crossbred cow is fed $8.41 \mathrm{~kg}$ of green fodder, $6.12 \mathrm{~kg}$ of dry fodder and $4.28 \mathrm{~kg}$ of concentrate per day. One local cow is fed with $4.78 \mathrm{~kg}$ of green fodder, $1.82 \mathrm{~kg}$ of dry fodder and $2.03 \mathrm{~kg}$ of concentrate whereas a buffalo is fed with $8.21 \mathrm{~kg}$ of green fodder, $7.57 \mathrm{~kg}$ of dry fodder and $3.87 \mathrm{~kg}$ of concentrate on daily basis. In case of crossbred cow and buffalo, green fodder is fed in highest quantity followed by dry fodder and concentrate is the least while in case of local cow, green fodder quantity is highest followed by concentrate and the least is dry fodder. Among all the herd size categories, maximum quantity of green fodder, dry fodder and concentrate was fed by large herd size category for all the three types of animals.

Table 4 shows the cost incurred per day per animal on feed and fodder. A perusal of the table indicates that about $50 \%$ of cost on feed and fodder is on concentrate and the least is on green fodder. Similar finding was reported by Kumawat et al. (2014) and Patel and Ashwar (2019). Among the different types of animals, cost incurred on feeding buffaloes (₹ 123.43) is the highest due to their huge appetite followed by crossbred (₹122.35) and the least is on local cows ( $₹$ 50.22). Also, the cost incurred on concentrate and green fodder was maximum for crossbred cow while that for dry fodder was maximum for buffalo. A crossbred cow was fed ' 9.58 worth green fodder, $₹ 39.25$ worth dry fodder and $₹ 73.52$ worth concentrate while a local cow was fed ₹5.52 worth green fodder, ₹11.99 worth dry fodder and ₹32.71 worth concentrate. Buffaloes were also taken for grazing on a regular basis and cost incurred on that was included in labour cost. The cost incurred on green fodder, dry fodder and concentrate was ₹9.31, ₹47.76 and ₹66.36, respectively in case of buffalo. The cost incurred increases with the herd size category which may be because the larger the herd size, more is the milk for disposal and thereby, more is the income. They have more financial strength to feed the animals. Better management practices could be 
another plausible reason as it ensures better feeding to animals which in turn increases the cost on feed and fodder.
Table 5 depicts the labour cost incurred per day per animal bifurcated into own family labour and hired labour. About $90 \%$ of the labour cost is imputed cost (non-cash cost) as most of the dairy related

Table 3 Quantity of feed and fodder fed to animal daily (kg/animal/day)

\begin{tabular}{lllll}
\hline Type of animal & Herd size category & Green Fodder & Dry Fodder & Concentrate \\
\hline Crossbred Cow & Small & 8.20 & 5.91 & 4.18 \\
& Medium & 8.33 & 6.40 & 4.38 \\
& Large & 9.96 & 6.61 & 4.61 \\
& Overall & 8.41 & 6.12 & 4.28 \\
Local Cow & Small & 4.57 & 1.74 & 1.98 \\
& Medium & 4.91 & 1.92 & 2.03 \\
& Large & 5.76 & 2.06 & 2.28 \\
Buffalo & Overall & 4.78 & 1.82 & 2.03 \\
& Small & 8.25 & 7.36 & 3.80 \\
& Medium & 7.70 & 7.78 & 3.93 \\
& Large & 9.48 & 8.28 & 4.14 \\
\end{tabular}

Table 4 Feed and fodder cost according to herd size category ('/animal/day)

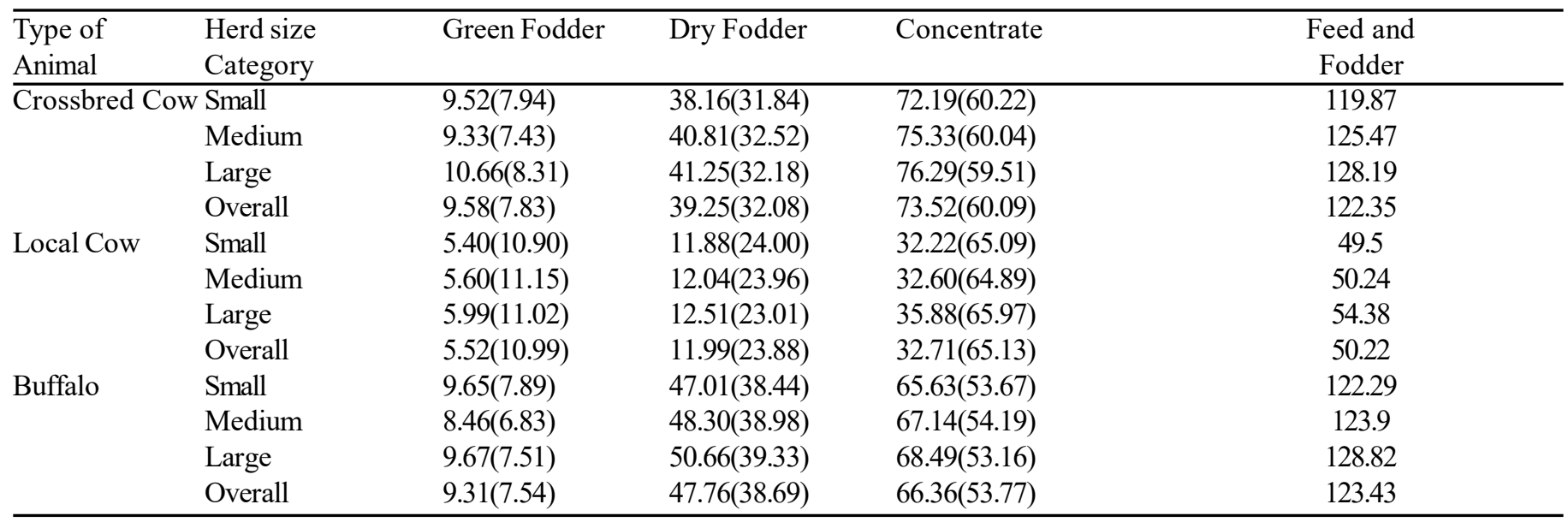

Note: Figures in parentheses shows the percentage of row total

Table 5 Labour cost according to herd size category and milch animal species

\begin{tabular}{llllc}
\hline Type of Animal & Herd size Category & Own labour cost & Hired labour cost & Total Labour Cost \\
\hline Crossbred Cow & Small & $116.07(98.05)$ & $2.31(1.95)$ & 118.38 \\
& Medium & $96.55(77.93)$ & $27.34(22.07)$ & 123.89 \\
& Large & $98.33(76.31)$ & $30.53(23.69)$ & 128.86 \\
Local Cow & Overall & $108.57(89.69)$ & $12.49(10.31)$ & 121.06 \\
& Small & $32.90(96.98)$ & $1.02(3.02)$ & 33.93 \\
& Medium & $32.41(87.35)$ & $4.69(12.65)$ & 37.11 \\
Buffalo & Large & $31.15(79.52)$ & $8.02(20.48)$ & 39.17 \\
& Overall & $32.58(92.06)$ & $2.81(7.94)$ & 35.39 \\
& Small & $69.51(96.21)$ & $2.73(3.79)$ & 72.25 \\
& Medium & $61.89(92.91)$ & $4.72(7.09)$ & 66.61 \\
& Large & $57.46(90.57)$ & $5.98(9.43)$ & 63.44 \\
\end{tabular}

Note: Figures in parentheses shows the percentage of row total 
activities are being done by the family members. In case of small farmers, the share of own family labour cost was as high as atleast $95 \%$. The own labour cost and hired labour cost was ₹ 108.57 and ₹ 12.49 , respectively for crossbred cow, ₹32.58 and ₹2.81, respectively for local cow while, $₹ 66.06$ and $₹ 3.65$, respectively for buffalo. It was also observed that the own labour cost decreased with increase in herd size whereas hired labour cost increased with increase in herd size for all the three bovine species. The total labour cost per animal per day was found to be ₹ 121.06 , ₹35.39 and ₹ 69.70 for crossbred, local cow and buffalo, respectively. As evident from figures, the labour cost was maximum for crossbred cows as they required high maintenance. As local cow had low productivity, hence they aren't given much care and hence the labour cost was least for them. Total labour charges per animal per day increased with herd size in case of both crossbred and local cows whereas in case of buffaloes, it decreased.

Table 6 depicts the various components of total cost incurred per day per animal in milk production. Total fixed cost varied between 12 per cent to 18 per cent of the total cost. It was highest in case of crossbred (₹37.80), followed by buffalo (₹29.08) and least for local cow (₹17.83). Total fixed cost increased with increase in herd size for all the three bovine species. The share of total variable cost was very much higher than total fixed cost. Similar finding was reported in various other studies too (Chand et al. 2017; Keerthi and Paramsivam, 2019; Kumari et al. 2016; Kumawat et al. 2016; Patel and Ashwar, 2019; Singh et al. 2017; Tanwar et al. 2012). In the case of crossbred, feed and fodder cost and labour cost had an almost equal share in total variable cost. The plausible reason for equal share of feed and fodder could be high availability of labour in eastern parts of India which increases the labour cost. In case of buffaloes, more than $60 \%$ of variable cost is feed and fodder cost indicating their higher appetite. Labour cost is highest for crossbred when compared to other type of animals as more maintenance is required for them. Value of dung was deducted from gross cost in order to arrive at net cost which is highest in the case of crossbred and least for local cow. Finally, the net cost of milk production per animal per day worked out to be ₹ 278.17 , ₹ 100.30 and $₹ 218.81$ for crossbred, local cow and buffalo, respectively. In case of crossbred cow and local cow, the net cost of milk production increased with increase in herd size whereas in case of buffalo, it was found to be highest for large herd size category followed by small and least for medium herd size category.

A perusal of Table 7 shows that price of milk is highest for buffalo milk (₹36.70/litre) owing to high fat quantity. Among all the types of animals, crossbreds are the most productive and the least are the local cows. The yield from crossbred, local cow and buffalo was found to be 13.15 litre, 1.65 litre and 6.21 litre, respectively. Such trend of yield among the different bovine species was observed by almost all the related studies (Keerthi and Paramsivam, 2019; Patel and Ashwar, 2019; Chand et al. 2017; Kumari et al. 2016; Kumawat et al. 2016; Singh et al. 2017; Tanwar et al. 2012) Also, the productivity of animals showed a positive correlation with the herd size. Cost per litre of milk was highest for local cow ( ' 60.94/litre) and least for crossbred (₹ 21.15/litre) because of their low and high milk productivity, respectively. Similar findings were reported by Chand et at. (2017), Keerthi and Paramsivam (2019) and Kumari et al. (2016). It was negatively correlated with herd size depicting economies to scale. Return per litre from milk was highest for crossbred cows and it varied positively with herd size. In case of local cow, return was found to negative for all herd size category. Keerthi and Paramsivam (2019) too reported high cost of milk production of local cow such that farmers incurred loss. Even though rearing of local cow is not profitable, then why do farmers still keep them? In order to find a reason for that, the total costs was bifurcated into cash and non cash costs. Cash costs included concentrate cost, hired labour cost and miscellaneous costs. All other feed and fodder other than concentrate were farm grown, hence had an imputed cost. When return over cash costs was calculated then it was found to be positive

Table 6 Net cost of milk production according to herd size category and milch animal species (₹ /animal/day)

\begin{tabular}{|c|c|c|c|c|c|c|c|c|c|c|c|c|}
\hline \multirow[t]{2}{*}{ Cost } & \multicolumn{4}{|c|}{ Crossbred } & \multicolumn{4}{|c|}{ Local Cow } & \multicolumn{3}{|c|}{ Buffalo } & \multirow[b]{2}{*}{ Overall } \\
\hline & Small & Medium & Large & Overall & Small & Medium & Large & Overall & Small & Medium & Large & \\
\hline Cost & (12.78) & (14.31) & (13.90) & (13.36) & (16.71) & (17.03) & (18.16) & (16.97) & (12.59) & (13.37) & (14.27) & (12.99) \\
\hline Cost & $(43.51)$ & $(42.92)$ & (42.82) & (43.82) & $(48.25)$ & $(47.10)$ & (47.19) & (47.79) & $(54.35)$ & (55.99) & $(57.23)$ & (55.12) \\
\hline Labour Cost & 118.38 & 123.89 & 128.86 & 121.06 & 33.93 & 37.11 & 39.17 & 35.39 & 72.25 & 66.61 & 63.44 & 69.70 \\
\hline Cost & $(0.75)$ & $(0.39)$ & $(0.24)$ & $(0.59)$ & (1.98) & (1.08) & $(0.65)$ & $(1.57)$ & $(0.95)$ & $(0.53)$ & $(0.32)$ & $(0.77)$ \\
\hline Total & 240.32 & 250.51 & 257.78 & 245.08 & 85.45 & 88.50 & 94.30 & 87.25 & 196.68 & 191.69 & 193.00 & 194.85 \\
\hline Variable Cost & $(87.22)$ & (85.69) & (86.10) & (86.64) & (83.29) & (82.97) & (81.84) & (83.03) & $(87.41)$ & (86.63) & $(85.73)$ & (87.01) \\
\hline Gross Cost & 275.53 & 292.35 & 299.40 & 282.88 & 102.59 & 106.67 & 115.23 & 105.08 & 225.01 & 221.27 & 225.11 & 223.93 \\
\hline Value of Dung & 4.70 & 4.79 & 4.52 & 4.71 & 4.73 & 5.00 & 4.54 & 4.78 & 5.30 & 4.94 & 4.58 & 5.12 \\
\hline
\end{tabular}

Note: Figure in parentheses shows the percentage of their respective total 
Fig. 1 Profit per litre, yield and cost per litre of milk production from crossbred, local cow and buffalo in various states

Note: S: Small herd size category, M: Medium herd size category, L: Large herd size category, O: Overall

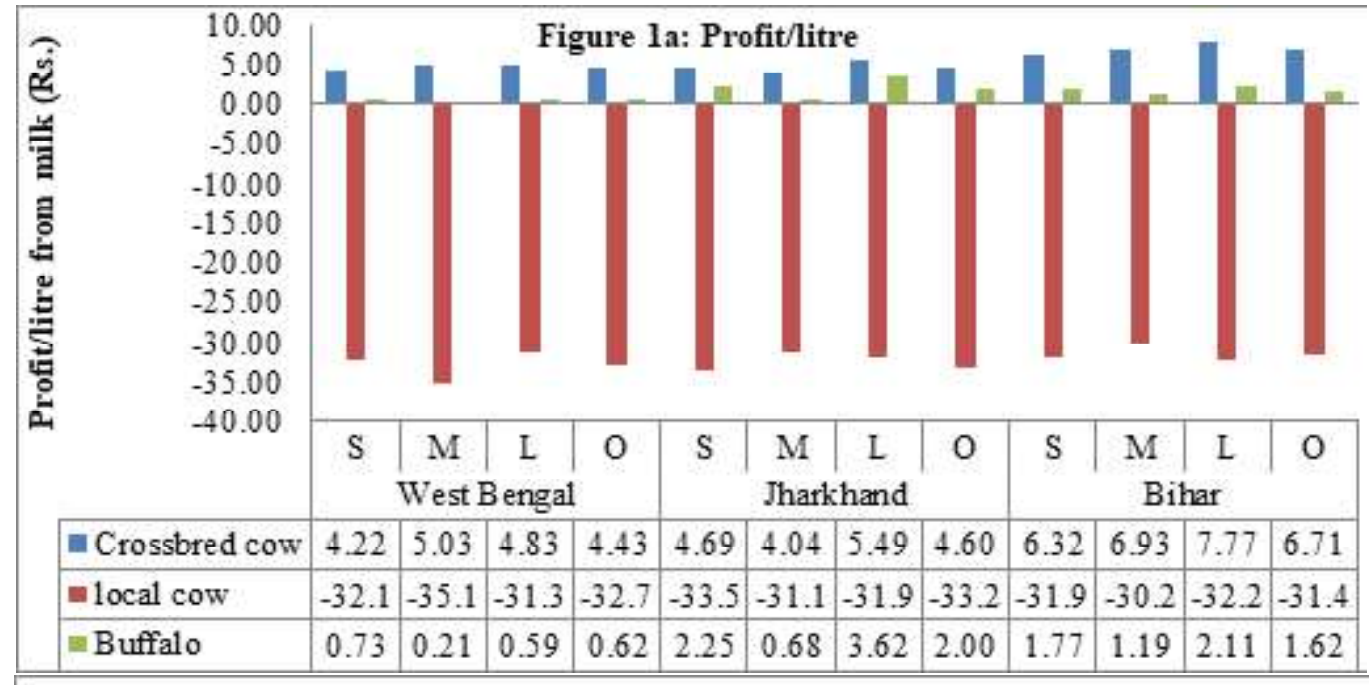

Figure 1b: Yield

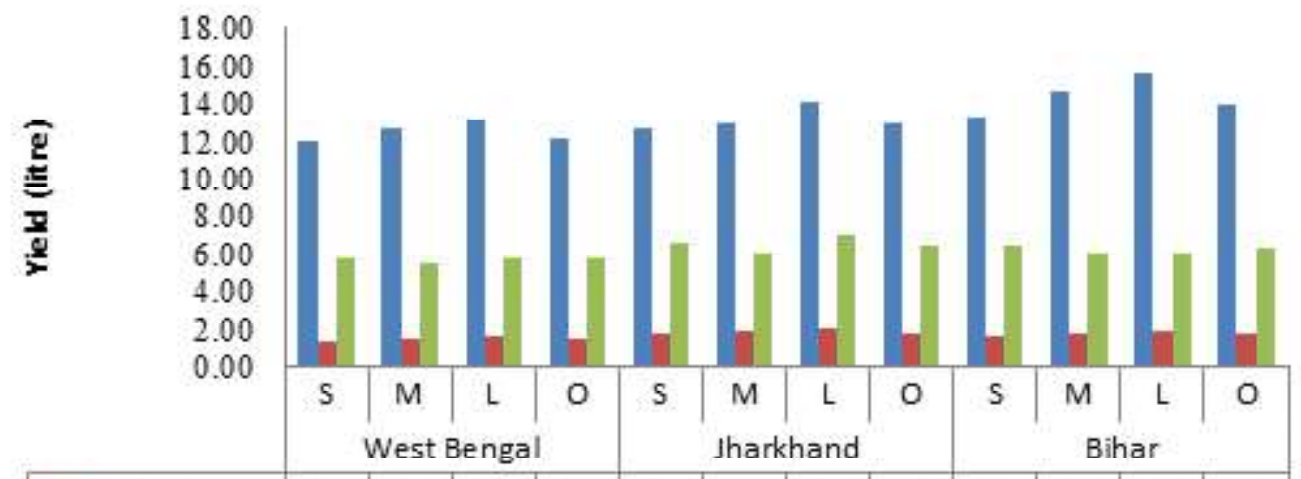

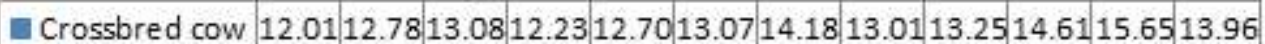

\begin{tabular}{|l|l|l|l|l|l|l|l|l|l|l|l|l|}
\hline E local cow & 1.41 & 1.43 & 1.66 & 1.45 & 1.74 & 1.88 & 2.01 & 1.78 & 1.68 & 1.76 & 1.87 & 1.73 \\
\hline B Buffalo & 5.81 & 5.45 & 5.82 & 5.74 & 6.61 & 6.01 & 7.08 & 6.48 & 6.44 & 6.14 & 6.07 & 6.30
\end{tabular}

Figure 1c: Cost/litre

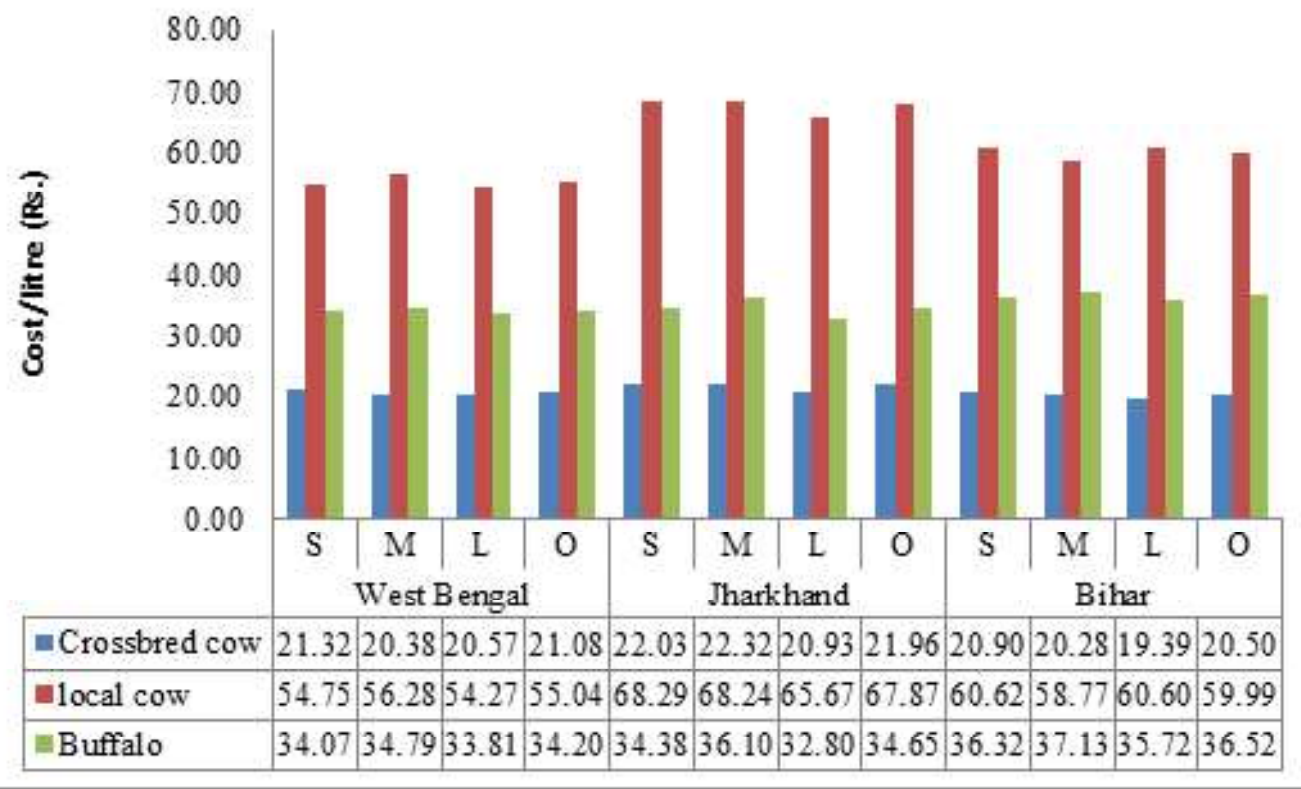


even for local cow. Farmers usually don't maintain a farm record and hence fail to realise the imputed cost incurred. Therefore, they rear local cow despite of it being a non-profitable enterprise. Thus, the return over cash costs per litre was found to be ₹ 20.20 , ₹ 8.54 and $₹ 25.97$ for crossbred cow, local cow and buffalo, respectively.

Figure 1 shows the diagrammatic representation of profit per litre, yield and cost per litre of milk production from crossbred, local cow and buffalo in various states. Profit per litre from local cow was negative in all the three sample states. It was highest in Bihar (₹6.71) for crossbred cow while in case of buffalo it was highest in Jharkhand (₹ 2.00). Yield from crossbred cow was highest in Bihar (13.9 litre) while that from local cow (1.78 litre) and buffalo (6.48 litre) was highest in Jharkhand. In all the three sample states the cost per litre of milk was highest for local cow followed by buffalo and crossbred cow.

Table 7 Returns per litre from milk according to herd size category (₹/animal/day)

\begin{tabular}{|c|c|c|c|c|c|c|c|c|c|c|c|c|}
\hline \multirow[t]{2}{*}{ Cost/Returns } & \multicolumn{3}{|c|}{ Crossbred } & \multicolumn{4}{|c|}{ Local Cow } & \multicolumn{4}{|c|}{ Buffalo } & \multirow[b]{2}{*}{ Overall } \\
\hline & Small & Medium & Large & Overall & Small & Medium & Large & Overall & Small & Medium & Large & \\
\hline $\begin{array}{l}\text { Price of milk } \\
\text { (/litre) }\end{array}$ & 26.50 & 26.54 & 26.54 & 26.51 & 28.23 & 28.25 & 28.05 & 28.22 & 36.52 & 37.09 & 36.64 & 36.70 \\
\hline $\begin{array}{l}\text { Average } \\
\text { daily milk yield }\end{array}$ & 12.66 & 13.67 & 14.57 & 13.15 & 1.61 & 1.66 & 1.80 & 1.65 & 6.28 & 5.96 & 6.49 & 6.21 \\
\hline Gross return & 335.44 & 362.70 & 386.76 & 348.63 & 45.56 & 46.85 & 50.44 & 46.44 & 229.47 & 220.89 & 237.64 & 227.86 \\
\hline Net Cost & 270.83 & 287.56 & 294.88 & 278.17 & 97.87 & 101.68 & 110.69 & 100.30 & 219.71 & 216.33 & 220.53 & 218.81 \\
\hline Net Return & 64.60 & 75.14 & 91.88 & 70.46 & -52.31 & -54.83 & -60.26 & -53.86 & 9.76 & 4.56 & 17.11 & 9.05 \\
\hline Cost/litre & 21.39 & 21.04 & 20.24 & 21.15 & 60.64 & 61.31 & 61.57 & 60.94 & 34.97 & 36.32 & 34.00 & 35.24 \\
\hline Return/litre & 5.10 & 5.50 & 6.31 & 5.36 & -32.41 & -33.06 & -33.52 & -32.72 & 1.55 & 0.77 & 2.64 & 1.46 \\
\hline Cash costs & 76.57 & 103.83 & 107.54 & 87.68 & 35.27 & 38.44 & 44.64 & 37.16 & 70.51 & 73.04 & 75.20 & 71.73 \\
\hline $\begin{array}{l}\text { Return over } \\
\text { cash costs/litre }\end{array}$ & 20.82 & 19.29 & 19.47 & 20.20 & 9.30 & 8.076 & 5.74 & 8.54 & 26.14 & 25.65 & 25.75 & 25.97 \\
\hline
\end{tabular}

Table 8 Coefficients of various variables regressed on income per household per day from selling of milk

\begin{tabular}{|c|c|c|c|c|}
\hline \multirow[t]{2}{*}{ Variables } & \multicolumn{3}{|c|}{ Coefficients } & \multirow[b]{2}{*}{$\overline{\text { Overall }}$} \\
\hline & Small & Medium & Large & \\
\hline Intercept & $\begin{array}{l}3.6726^{*} \\
(0.2888)\end{array}$ & $\begin{array}{c}4.4719 * * \\
(0.6956)\end{array}$ & $\begin{array}{c}6.1184 * * \\
(1.3363)\end{array}$ & $\begin{array}{l}3.4680 * * \\
(0.2249)\end{array}$ \\
\hline $\begin{array}{l}\text { Expenditure on } \\
\text { green fodder per } \\
\text { farm per day }\end{array}$ & $\begin{array}{c}0.0528 \\
(0.0279)\end{array}$ & $\begin{array}{c}0.1278 * * \\
(0.0481)\end{array}$ & $\begin{array}{c}0.2856 * * \\
(0.0893)\end{array}$ & $\begin{array}{c}0.1214 * * \\
(0.0243)\end{array}$ \\
\hline $\begin{array}{l}\text { Expenditure on dry } \\
\text { fodder per farm per } \\
\text { day }\end{array}$ & $\begin{array}{c}0.2503 * * \\
(0.0369)\end{array}$ & $\begin{array}{c}0.0518 \\
(0.0929)\end{array}$ & $\begin{array}{c}0.2952 \\
(0.2264)\end{array}$ & $\begin{array}{c}0.2462 * * \\
(0.0332)\end{array}$ \\
\hline $\begin{array}{l}\text { Expenditure on } \\
\text { concentrate per } \\
\text { farm per day }\end{array}$ & $\begin{array}{c}0.1351 * * \\
(0.0400)\end{array}$ & $\begin{array}{c}0.2355^{* *} \\
(0.0792)\end{array}$ & $\begin{array}{c}0.1765 \\
(0.1446)\end{array}$ & $\begin{array}{c}0.1362 * * \\
(0.0363)\end{array}$ \\
\hline $\begin{array}{l}\text { Value of labour } \\
\text { used per farm per } \\
\text { day }\end{array}$ & $\begin{array}{c}0.2387^{* *} \\
(0.0332)\end{array}$ & $\begin{array}{c}0.1634^{* *} \\
(0.0479)\end{array}$ & $\begin{array}{c}0.0560 \\
(0.1125)\end{array}$ & $\begin{array}{c}0.2303 * * \\
(0.0272)\end{array}$ \\
\hline $\begin{array}{l}\text { Miscellaneous } \\
\text { expenses per farm } \\
\text { per day }\end{array}$ & $\begin{array}{c}-0.1418^{*} \\
(0.0746)\end{array}$ & $\begin{array}{c}0.1091 \\
(0.1087)\end{array}$ & $\begin{array}{l}0.4930 * \\
(0.2262)\end{array}$ & $\begin{array}{c}-0.1076 \\
(0.0625)\end{array}$ \\
\hline R-square & 0.6150 & 0.2813 & 0.4156 & 0.7156 \\
\hline $\mathrm{N}$ & 182 & 88 & 30 & 300 \\
\hline
\end{tabular}

Note: Figures in parentheses are the standard errors. ${ }^{*} 5$ per cent level of significance, ${ }^{* *} 1$ per cent level of significance 
Table 8 shows the coefficients obtained when expenditure incurred on green fodder, dry fodder, concentrate, labour and miscellaneous inputs per farm per day are regressed on income from sale of milk. Log-log functional form was found to be the best fit. A perusal of Table 8 indicates that the expenditure on dry fodder, concentrate and labour used per farm per day had a positive and significant impact on income from sale of milk in the case of small dairy farmers whereas miscellaneous expenditure had a negative impact. Similarly, in the case of medium farmers, expenditure on green fodder, concentrate and labour used had a positive and significant impact whereas for large farmers, expenditure on green fodder and miscellaneous expenditure had a positive and significant impact. Therefore, $1 \%$ increase in expenditure on green fodder, dry fodder, concentrate and labour per farm per day leads to $0.1214 \%, 0.2462 \%, 0.1362 \%$ and $0.2303 \%$ increase in income per household per day, respectively while an increase of $1 \%$ in miscellaneous expenses per farm per day decreases the income per household per day by $0.1076 \%$. and In nutshell, for overall category the income from sale of milk can be increased if expenditure on green fodder, dry fodder, concentrate and labour used are increased. But to what extent the expenditure should be increased? Well, this dilemma can be overcome by equating marginal value productivity of these inputs with their unit prices. The MVP of these significant inputs, i.e, expenditure on green fodder, dry fodder, concentrate and labour used were found to be $2.16,1.01,0.44$ and 0.59 , respectively. The MVPs indicate that green fodder are overused, dry fodder is used optimally, whereas, concentrate and labour are under used.

\section{Conclusions}

There is a good scope for dairy development in eastern India. The growth rate of milk production in the region is about 4 per cent and if profitability is to be maintained in the enterprise then the farmer must take care of both cost incurred in milk production and the yield with more emphasis on lowering cost of production as yield can be increased only to an extent. About fifty per cent of total feed and fodder cost is incurred on concentrate and the least is on green fodder. Cost incurred on feeding buffaloes is maximum followed by crossbred and local cows. About ninety per cent of the labour cost is imputed cost of own family labour. Return per litre from milk is highest for crossbred and negative for local cow and it varied positively with the herd size. When non-cash costs is excluded and only cash costs are taken into account then only returns from local cow milk production were found to be positive. Also, the farmers in the study area are over using green fodder, optimally using dry fodder and under using concentrate and labour in milk production.

\section{References}

Bhagat AA, Bhoge RS, Bajaj VH, Fernandes AP (2016) Milk production function and resource use efficiency in pandharpuri buffalo. Bioinfolet 13: 346-347

Chand P, Sirohi S, Mishra A, Chahal VP (2017) Estimation of costs and returns from dairying in Malwa region of Madhya Pradesh. Indian J Anim Sci 87: 381-386

Kumari B, Malhotra R, Chauhan AK (2016) Impact of women dairy cooperatives on economics of milk production in Begusarai district of Bihar. Indian J Dairy Sci 69: 487-491

Kumari B, Malhotra R (2018) Milk production function and resource use efficiency of women dairy co-operatives in Begusarai district of Bihar. Indian J Dairy Sci 70: 98-101

Keerthi S, Paramasivam P (2019) Economics of milk production in southern transition zone of Karnataka. Int J Farm Sci 9: 82-86

Kumawat R, Pramendra, Singh NK (2016) Analysis of cost and returns of milk production in Rajasthan. Economic Affairs 61: 71-74

Lalrinsangpuii, Malhotra R (2016) Resource use efficiency in milk production in Mizoram state of north-east. Indian J Anim Sci 6: 431-435

Mehra K, Singh V, Nazir H (2018) Resource use efficiency in milk production and milk utilization pattern of milk producers in hilly areas of Kumaon region of Uttarakhand. Int J Pure App Biosci 6:736-743

Patel N, Ashwar B (2019) Factors in economics of milk production on commercial dairy farms in Aravalli district of north Gujarat. Indian Res J Ext Edu 19: 83-88

Sirohi S, Bardhan D, Chand P (2015) Costs and returns in milk production: developing standardized methodology and estimates for various production systems. Project Report submitted to Department of Animal Husbandary, Dairying and Fisheries, Ministry of Agriculture, Govt. of India, New Delhi

Singh JK, Singh R, Singh JP, Mishra SK, Kumar R, Raghuvanshi T (2017) A study of cost and returns of milk production of cow and buffalo and to find out the break even point of dairy enterprise; in Faizabad district of eastern Uttar Pradesh, India. Int J Curr Microbiol App Sci 6: 3928-3938

Tanwar PS, Kumar Y, Sankhala G (2012) Economics of milk production among member and non-member families of dairy cooperatives in Jaipur (Rajasthan). Indian J Dairy Sci 65: 405-409.

Vishnoi S, Pramendra, Gupta G and Pooniya R (2015) Milk production function and resource use efficiency in Jaipur district of Rajasthan. African J Agric Res 10: 3200-3205 